\title{
Community Versus Assimilation: A Study in American Assimilation at Saint Joseph's Indian Industrial School
}

\author{
Sarah Shillinger \\ University of Wisconsin-La Crosse
}

\begin{abstract}
No government policy has had more of an impact on American Indians than the boarding school movement of the early to mid-twentieth century. This movement isolated American Indian children from their homes and communities and attempted to assimilate them into European-American society. This article studies the effects of this policy on children at the Saint Joseph's Indian Industrial School in Wisconsin. It uses oral history to recapture the voices and experiences of teachers and students. The use of oral history allows a comprehensive understanding of the cultural, social and academic atmosphere of the school.
\end{abstract}

Dairy farms border both sides of Wisconsin Highway 47 until you enter the Menominee Indian reservation, Then, as though somebody had inscribed a line with a knife, the forest begins. Just before you drive through Keshena, the reservation's largest village, a large open space off to the right marks the site where Saint Joseph's Indian Industrial School once stood. Operated from 1883 to 1952, Saint Joseph's was a Catholic American Indian boarding school. The Complex was large with frame and brick buildings, dormitories, a church, fields, and a small dairy farm. The school is now completely gone. All that remains is a graveyard and the church. These are the only remaining physical symbols of the strong impact that Saint Joseph's had on the Menominee tribe. This paper will explore and analyze the lasting impression that Saint Joseph's has had on the tribe. 


\section{Research Method}

Researching American Indian boarding schools is not an easy task. Few written records exist, and those that do tend to be financial records and official correspondence written by the school's administration. These records were not written by and contain few allusions to either teachers or students. The only way to recapture the experiences and voices of the teachers and students is through oral history interviews. This paper is based on a series of oral interviews done between 1991 and 1994. Many former students were located using Saint Joseph's written records in the archives of Marquette University in Milwaukee, Wisconsin. Others were located with the help of the personnel of the Potawatomi and Menominee tribal offices. The interviewed teachers were identified through the Motherhouse of the Sisters of Saint Joseph's De Caroundelet in Saint Louis, Missouri.

Once identified, informants were contacted and asked for interviews. After they agreed, interviews were scheduled at a time and place of their choosing. Interviews were held in places ranging from the cafeteria at the Satin Joseph's Motherhouse to informants' living rooms on the reservations.

At the beginning of each interview permission was obtained to tape the interview and informants were told that their testimony would be used for publication and the tapes placed in a public archive. Also at this time a recorded oral copyright was obtained. After the project was completed the tapes were placed in the archives of Marquette University where they are available for use by researchers.

The information from the oral documents was combined with the information from the written records. Bias in both sets of documents were taken into consideration; however, written information was not assumed to be more accurate than oral information. The two sets of documents show different perceptions, and both sets are valid. For example, many of the written documents stress the financial difficulties Saint Joseph's faced; however, the oral documents state that the school was financially well off. These statements reveal different perspectives. The school had great difficulty procuring adequate funding for books and other educational equipment. Funds for maintaining buildings and grounds were limited throughout Saint Joseph's history. From the perspective of an administrator writing to the Bureau of Catholic Indian Missions (BCIM), the school was in desperate financial straits. Impoverished students had a very different perspective of the school's finances. Some of the students' parents sent them to Saint Joseph's because they could not afford to adequately feed and clothe their children through the winter. To such students Saint Joseph's appeared wealthy. 


\section{The School}

Saint Joseph's Indian Industrial School was founded in 1883 as part of a federal policy to assimilate American Indians into mainstream American society. The boarding school movement began in the 1870's when Richard Pratt, an ex-army officer turned educator, envisioned a series of boarding schools where American Indian children could be completely isolated from their tribal communities.

Pratt, determined to prove that American Indians could be taught to live and think like European-Americans, set up a model school in Carlisle, Pennsylvania. Pratt chose the location because Pennsylvania had no American Indian reservations, and students could be completely isolated from tribal influences. The Carlisle school and its isolation policy quickly gained widespread acceptance among federal policy makers, missionary groups, and other "friends of the Indians" who wished to ensure the assimilation of American Indians. Children were to be educated to eschew all aspects of their tribal culture. In his 1889 Supplemental Report on Indian Education, Indian Commissioner Thomas Jefferson Morgan wrote that American Indians "should be educated not as Indians, but as Americans. In short the public school should . . . assimilate them." Morgan also instructed all American Indian boarding school officials that when teaching American Indian students, to "carefully avoid any unnecessary reference to the fact they are Indians."

A later Indian Commissioner, Ezra Hayt, echoed Morgan's views when he wrote, "The exposure of children who attend only day-schools to the demoralization and degradation of an Indian home neutralize the efforts of the school teacher, especially those efforts which are directed to advancement in morality and civilization." 3

By 1880 the Indian Office (the federal department charged with overseeing American Indian tribes) began contracting with various religious denominations to operate boarding schools using the Carlisle school as a model. Saint Joseph's Indian Industrial School in Keshena, Wisconsin, operated under a contract between the BCIM and the Indian Office. The Bureau, located in Washington, DC, was responsible for administering all of the Catholic Church's boarding school contracts. The BCIM subcontracted out the actual running of each boarding school to various religious orders.

Problems with Saint Joseph's contract began shortly after the school opened. Many of these problems were common to Catholic boarding schools. Payments from the Indian Office, which were routed through the $\mathrm{BCIM}$, often arrived late. In addition the BCIM remained responsible for the school's operation without day-to-day knowledge of the school's operation. However, at Saint Joseph's and other boarding schools located on Indian reservations, the most serious problem from an assimilationist point of view was the difficulty of removing students from their tribe's 
influence.

\section{Isolation at Saint Joseph's}

Although the federal boarding school policy emphasized the removal of students from tribal influences, Saint Joseph's location just north of Keshena made total physical isolation virtually impossible. Saint Joseph's administration tried to compensate for the lack of physical isolation by creating a wall of social and cultural seclusion around the school. Students and teachers were not permitted to interact with the tribal community. The result was a hostile environment in which neither teachers nor students thrived.

In the oral documents isolation is a common theme which was almost as profound for the teachers as it was for students. The teachers rarely left the school grounds. For example, during the time Saint Joseph's operated, the tribe derived most of its income from the operation of a sawmill in Neopit, a village located about ten miles for Keshena. The sawmill, operated under the rules of a mainstream business, was tangible evidence that if the Menominee would accept individual jobs, become part of a modern work force, and relinquish their American Indian culture, then economic prosperity was assured.

The sawmill represented the same goals that were being taught at Saint Joseph's. According to the BCIM's contract the main purpose of Saint Joseph's was to assimilate Menominee children. The sawmill was also designed to assimilate Menominee tribal members. Despite the similar intentions contact between the sawmill and the school was minimal. The teaching sisters were often frustrated by their isolation. Sister Charles Helene expressed regret that although she was in Keshena for nine years, "I never did get to the mill and everybody that came to visit went up to the mill and I never did get to the mill." 4 Sister Mary Elreda, the sisters' superior in the 1940's, remembered, "I got up to the mill about a year after [I arrived] because I insisted." ${ }^{5}$

The isolation of the teachers is remarkable precisely because it seems so impossible. The lives of the teachers were structured in a manner designed to filter out influences from the tribal environment that surrounded them. There were two ways that this isolation was accomplished. First, every moment of their day was regulated. The teachers were responsible for every aspect of the students' care from fixing meals to teaching mathematics. There simply was not time for the teachers to interact with the tribal community even had they been so inclined.

The second reason is much more subtle: the religious framework in which the teachers lived. All of the permanent teachers were from religious orders. Most of the teachers were members of Sisters of Saint Joseph, headquartered in Saint Louis, Missouri. There were also several male high school teachers and administrators who were mem- 
bers of the Franciscans located in Saint Louis. On occasion a nonreligious teacher was hired to teach specific skills (for example, an itinerant shoemaker was hired temporarily to teach cobbling). The religious vows that the sisters made meant that their lives were structured around their mission: the school.

The sisters were not just isolated from the tribe; they were also isolated from Saint Joseph's administrative and financial problems. For example, on January 16, 1933, Father Engelhard, the school's administrator, had received the quarterly check for the Bureau and deposited it in the Bank of Sawano. Two weeks later the bank closed. The school lost $\$ 2,000$, precipitating a financial crisis. When I asked former teachers about this incident during interviews, they stated that they were unaware of it. Sister Mary Evangela said, "I don't even remember Father [Engelhard] ever mentioned that he had any money in that bank." 6 This was confirmed by Sister Charles Helene who said, "He never did mention anything [about money]."7

This situation is ironic because the sisters were not simply employees who were paid for their labor. In theory the sisters were equal partners in the running of Saint Joseph's. The Sisters of St. Joseph's made a considerable financial contribution toward maintenance of the school This contribution was acknowledged by Paul Frickinger, the Associate Director of Education for the Indian Office. He wrote, "Under the terms of the annual mission contract the tribe pays $\$ 125$ a year per pupil, whereas the cost of the boarding school when operated by the federal government was more than $\$ 300$ per capita." ${ }^{8}$ Frickinger went on to explain that the "difference in cost is due to the fact that the Sisters serve without pay." 'Despite this contribution, Saint Joseph's was always understaffed. In 1885 the school had twelve teachers: six sisters, one lay teacher, and five male teachers. At that time, Saint Joseph had 150 students. Although the student/teacher ratio is reasonable at 12.5 students per teacher, this figure is misleading because teachers did not simply educate. They were expected to provide all necessary services to students and were never off duty. Former teachers remember the long hours:

get up at five o'clock, had to be in the chapel at twenty after five, and we had prayers and meditation; at about ten to six we went to church. We had mass at six thirty ... [We got up at] four thirty in the morning at the boy's school. You'd get up and stoke the fire. You'd get on these big containers of water to make their cereal [and] their drinks. One sister had to stay [at home and not go to mass] and [we] took turns, like, if I stayed this week, then [the] next week the other sister [would]. When we got home everybody had a job. We either went to the 
children's dining room or we went upstairs and made our beds or something . . . Then the bell would ring when breakfast was ready and you answered the bell and you either had school or something and then at five to eight you went to church with the kids for eight o'clock mass. [At] eight thirty, we went to school . . . and then we taught until three o'clock. But [because of] my duties in the mornings, I did not go to school . . . . I took kids I had there .... . The fifth and sixth [graders] only went to school a half a day because they had to help around the house. I would take a group and we'd clean a dormitory today and tomorrow we'd clean another dormitory and then one day we'd clean part of the school. We worked like you'd not believe. Three o'clock, school was over and then we'd come over to take care of all the playrooms and then we'd take care of the children 'till we put them to bed. ${ }^{10}$

However, putting the students to bed did not end the teachers' day. Teachers were expected not only to teach but also to serve as dorm mothers and surrogate parents. Sisters slept in cubicles that were curtained off from the students' dormitory. As this 1930s anecdote from Sister Charles Helene illustrates, lack of privacy was a continuing problem.

One night I slept right in the dormitory with the girls and I remember this one night, this child must have been walking in its sleep .... I think this child tried to get in bed with me. Well I woke up and here was this ... little girl .... I t took her back to bed and tucked her in and she slept the rest of the night. But she frightened me. ${ }^{11}$

This occurrence was not isolated. Sister Mary Ignace remembers a similar incident:

I felt a tap on my shoulder. I sat up and I did not see anything. 'Cause [at] first we just had a curtain around our beds . . . and I looked around and finally I looked down and here was this little kid and as soon as she saw that I saw her she turned around. She was new and she couldn't open the back of her little pajamas. After I opened her up [she went] down the hallway. We had a toilet down there at the other end of the hallway . ... she then came back to my cell and turned around. I buttoned her up and she went back to bed. That took care of that. ${ }^{12}$ 
The School's administrators tried to eliminate, or at least minimize, the interaction of the students with the tribal environment; however, this task proved to be almost impossible. Students developed a series of tactics to circumvent the school's isolation attempts.

In keeping with its isolation policy, Saint Joseph's severely limited home visitation. Home visitation was discouraged by the Pratt Plan and federal policy. Pratt's model school in Carlisle, Pennsylvania, permitted no home visitation at all until the student graduated. School vacations were spent with European American families. Called outings, this program was designed to expose students to actual European American home life and to prevent any interaction with their tribal communities that might interfere with the school's assimilation policy. Saint Joseph's followed this policy by only exposing students considered either by the local Indian agent or by the school to be sufficiently assimilated. Irene Pywasit, a Menominee student, recalled that students who failed to conform were given demerits, and "If we got too many demerits we couldn't go home ... for the summer."13 Sister Ann Agatha, a teacher at the same time, confirms that the administrator knew "who was privileged to go home and the rest had to stay. Some stayed for two weeks; some stayed for the whole month. [Others] went home ... once a month."14

At Saint Joseph's students who missed their homes often ran away. Although it is impossible to estimate the exact number of runaways because of the lack of written sources dealing with the issue, it appears to have been a significant problem. Most of the former students interviewed for this oral history admitted to running away from the school at least once. Mildred Kaquatosh, an orphan who ran away, was proud of the fact that "the police didn't get me."15

Most of the evidence on runaways comes from the students themselves. All of the teaching sisters were unwilling to discuss runaways. The teachers did, however, mention a few revealing facts. Sister Mary Ignace said, "Father Engelhard would always go out when the girls would go." Sister Mary Evangela remembered, "One time this girl ran away from school and poor Father Benno had to go out and catch her. He stopped at the [student's] house and of course she wasn't there. He just happened to look up and there she was sitting ... [on the] rafters hiding from him."16

Perhaps the most revealing point about this story is Sister Mary Evangela's way of telling it. She assumed that the student's family would not return the girl to school or help Father Benno Tushaus locate her.

Saint Joseph's policy not only separated students from the parents and tribal community, but also separated siblings. This was an extension of the policy followed at Carlisle. Pratt ordered students from 
the same tribe to be separated immediately after entry into the school. This was not possible at Saint Joseph's because the student body was largely Menominee. Instead, to lessen family and by extension tribal ties, the administration separated children from the same family. Catherine Waukecheon, another student, remembers losing contact with family members. "There were seven of us in my family, but they were the big kids. We were there . . . we were in the same building but we weren't together. I missed the boys [my brothers]."17

Josephine Daniels, a student, remembers the impact separation had on her sister, Elsie:

Mother Superior came ... over .... She says that she was Mother Superior [and] to call her mother. I looked at her and I looked at my sister and I told my sister we were supposed to call her mother. And my sister says I know my mother and she says, "I am not going to call her mother." They introduced us to another nun there [and] ... she took my sister and went and put her in a ... little girls' room downstairs kind of in back of the ... building .... Then I heard my sister screaming away and I wanted to run to my sister and they grabbed ahold of me and she said ... I couldn't go .... I yanked away from her and I went to my sister and she was in a corner: sitting in a corner. I [asked] her, "What's the matter? What are you screaming about?" She says, "I'm scared of these people."18

The policy of separating siblings was only partially successful in isolating students because it failed to take into account the clan structure of the tribe. Like most American Indian tribes the Menominee tribe is organized into clans. Among the Menominee children are members of their father's clan. Cultural and religious beliefs maintain that all members of a clan are related. Saint Joseph's attempts to lessen the ties between siblings rarely succeeded because of the strength of the clan bond.

Frances Walker, a former student, remembers her first night as a student at Saint Joseph's:

I was lying there .... I didn't really know anybody ... 'cause my relatives were all in higher grades .... . I remember sitting up ... and another girl sat up ... and she waived to me .... I looked at her, Oh, my land ... it was like ... there's someone in this room with me.... Then a couple of the others sat up and then they waved to me ... thought ... I got five relatives in this room. ${ }^{19}$ 
Frances Walker was referring to fellow clan members. As long as these bonds were in tact, assimilation into European American culture would be extremely difficult for the school to achieve.

Students also found ways to circumvent the school officials' attempt to isolate them from each other. Irene Pywasit remembers deliberately breaking school rules in order to be sent to the boy's building for discipline. She remembered that it gave her a chance to see her male cousins. The only other time male and female students saw each other was in church where they were not allowed to speak to one another.

\section{Language Isolation}

Another form of isolation imposed on students was the immediate substitution of English for the tribal language. One of the first steps toward this goal was the creation of an English-only environment. Federal govemment Indian policy insisted that students speak and be addressed only in English. John Atkins wrote in the 1887 Report of the Commissioner of Indian Affairs that, "The first step ... towards teaching the Indians the mischief and folly of continuing in their barbarous practices is to teach them the English langauge. ${ }^{n 20} \mathrm{He}$ went on to write of the "impossibility of civilizing the Indians in any other tongue than our own would seem to be obvious." Most of Saint Joseph's students learned English within their first year at Saint Joseph's, "making replacement of Indian languages with English the most successful of all attempts at assimilation."21

The transition from Menominee or Potawatomi to English was not always an easy one for students. Tillie Sayresrun recalled that when she first arrived at the school, the teachers had, "a student [tell] me in my language that I shouldn't talk my language. I had to learn English. . .. 'Otherwise the nuns would get after us ....' So that's what I did. I was scared of them so I guess my English was scared into me when I was in the first grade."22

The school's English-only policy was strictly enforced. The students remember several approaches that were used with students who were slow to adopt the English language. Irene Pywasit recalled that, "If we were caught speaking our language we were punished severely. We might get a kerosene shampoo or a bar of yellow soap shoved in our mouth-that was just part of it." ${ }^{\text {23 }}$

The students' acceptance of the forced change to English was further complicated by the fact that many of the teachers and administrators were not themselves Native English speakers. In 1890, the English language proficiency of Saint Joseph's faculty became a major issue between the Indian Office and the school's administrators. In a report to the Bureau of Catholic Indian Missions, Father O'Doric Derenthal stated that the teachers, "except four [were] born American, and of the 
foreign born only two - our carpenter and baker-are not able to [speak perfect English. However,] they can get along."24

Another complicating factor was that the English-only standards applied only to students. Frank Keshena remembers a 1930s incident: As a tribute to Father Engelhard, they, "were taught to sing ... 'O Christmas Tree' ... in German. That's a German song and we were taught to sing that in German ... the entire school of Indian students." ${ }^{25}$ The dual standard confused many students. The message some students received was that it was acceptable to speak German, a European language, but not Menominee, an American Indian one. This double standard negated the message the teachers were theoretically sending that it was necessary for everyone to speak English in the United Sates for economic reasons. Despite problems with English, most students did learn to use English exclusively in public. Linguistic conformity, however, did not mean, as school and Indian office official believed, cultural conformity.

\section{Marginalization}

Despite the attempts of Saint Joseph's officials to assimilate American Indian students into mainstream culture, many students resisted these efforts strenuously. In order for the school to assimilate its students, European American customs and language had to be substituted for tribal customs and language. This was the ultimate purpose of the school's isolation policy. This policy did not succeed. Its failure, however, did not mean that the students were unaffected by the school's assimilation policy. Students acquired some European American values and behaviors while at Saint Joseph's; however, they often found these attitudes unworkable and the behaviors impossible to maintain once they left Saint Joseph's. Josephine Daniels, for example, who returned to her parents at the age of fourteen, described her first encounter with them.

The nuns told me, 'Go into the parlor,' the visitors' parlor. They said, 'Your mother is here.' I said, 'I don't have no mother.' 'Yes you do, Josephine, she's in there.' So I went running in and looked around. I seen a little bitty woman . . . sitting in the corner. She looked like a little girl and I come running out and I said, 'I never see no mother in there.' I said, 'What you call a mother?' [They said] 'Yes, your mother is in there.' 'No she's not,' I says. It made me laugh-she's real short, shorter than me. She's skinny. My mother imagery was big tall German type woman... When my father came, it was worse yet. My father was stocky and real muscular, a 
lot [like a] bull and [like a] little bulldog ... That's what I thought when I seen him ... My father imagery was very different. My father imagery was like Father Engelhard-real kind, genteel, soft, old and gray.... It was hard for me to identify with my father-you know, my father use to talk-well like real Indian languagewhere Father Engelhard had real fine speech . . . . I came back here [to the Potawatomi tribe]. ${ }^{26}$

Daniels remembers her difficulty in becoming part of tribal life again. It "was just different . . . . I couldn't understand the neighbors. The [other] children didn't like me either because I was curling my hair ... and always ironing my clothes .... Nobody [on the reservation] ironed clothes, and nobody curl[ed] their hair. They were always out picking berries or weeding gardens. ${ }^{27}$

Daniels' adjustment problems extended beyond her immediate tribal environment to rejection by the larger society. She missed her "church terrible." The first time she attempted to go to church, "everybody just looked at me and glared." Daniels then tried to attend Catholic religious training, where they told her

'We don't have no Indians here.' The priest, he just kind of looked at me and just looked over my head. All the other students were saying that Indians are pagans .... I I just said 'all right' and took my catechism and I walked off .... I I was a real good religious student. I tried to go to church but I couldn't so that crumbled. When your religion crumbles something else crumbles too. Like an old horse [you] just lay down [and] have a hard time getting up. ${ }^{28}$

These incidents ended Josephine Daniels' formal involvement with the Catholic Church and her attempts to assimilate into European American society. She eventually readjusted to life on the Potawatomi reservation as well as becoming an accepted and influential elder. However, in her words, the readjustment "was a trauma to me."29

\section{Conclusion}

Assimilation is the mutual accommodation of two parties. It requires both the desire and the willingness of the person attempting to change and the acceptance of the group into which the person is being assimilated. Neither was present here. Saint Joseph's isolated students from their tribal environments and submerged them in a European American culture, a culture where they were never comfortable 
nor accepted. Ironically, whenever they did enthusiastically embrace the values and behaviors of the European American culture, they were not treated as equals by members of that culture. The result was inevitable: former boarding school students were neither fully members of their tribal cultures nor, as the school administration hoped, were they indistinguishable from European Americans.

\section{NOTES}

'Thomas Jefferson Morgan, Supplemental Report on Indian Education, 1 December 1889, House Executive Document Number 1, 51st Congress, 2nd Session, Serial 2841, cixvii, in Francis Prucha, ed. Documents of the United States Indian Policy (Lincoln, NE: University of Nebraska Press, 1975), 180.

${ }^{2}$ Thomas Jefferson Morgan, "Instruction to Indian Agents in Regard to Inculcation of Patriotism in Schools," House Executive Document, Number 1, 51st Congress, 2nd Session, Serial 2841. cixvii in Prucha, 1975, 181.

${ }^{3}$ Ezra Hayt, quoted in Francis Prucha, The Great Father: The United States Government and the American Indian (Lincoln, NE: University of Nebraska Press, 1984), 232.

${ }^{4}$ Sister Charles Helen Frecker, oral history interview, St. Louis, Missouri, 29 July 1993. The tape of this interview is available to researchers at the Marquette University Archives in Milwaukee, Wisconsin.

${ }^{5}$ Sister Mary Elreda Willet, oral history interview, St. Louis, Missouri, 29 July 1993. The tape of this interview is available to researchers at the Marquette University Archives in Milwaukee, Wisconsin.

${ }^{6}$ Sister Mary Evangela Gribbon, oral history interview, St. Louis, Missouri, 29 July 1993. The tape of this interview is available to researchers at the Marquette University Archives in Milwaukee, Wisconsin.

${ }^{7}$ Frecker.

${ }^{8}$ Paul Frickinger, Letter to Superintendent, Keshena Agency, 1 October 1940. Located in Bureau of Catholic Indian Mission Series 1 Correspondence files for Wisconsin, Green Bay Agency, Menominee Reservation, Saint Joseph's Indian Industrial School, 1940, in the Marquette University Archives, Milwaukee, Wisconsin.

${ }^{9}$ Frickinger. 
${ }^{10}$ This is a compilation of oral histories recorded 29 July 1993 of Sister Mary Ignace, Sister Mary Elreda Willet, and Sister Ann Agatha Muser. All of these informants were teachers at Saint Joseph's Indian Industrial School in the 1930s and 1940s. The tapes of these interviews are available to researchers at the Marquette University Archives in Milwaukee, Wisconsin.

${ }^{11}$ Frecker.

${ }^{12}$ Ignace.

${ }^{13}$ rene Pywasit, oral history interview, Milwaukee, Wisconsin, 17 July 1991. The tape of this interview is available to researchers at the Marquette University Archives in Milwaukee, Wisconsin.

\section{${ }^{14}$ Muser}

${ }^{15}$ Mildred Kaquatosh, oral history interview, Neopit, Wisconsin, 27 June 1994. The tape of this interview is available to researchers at the Marquette University Archives in Milwaukee, Wisconsin.

\section{${ }^{16}$ Frecker}

${ }^{17}$ Catherine Waukecheon, oral history interview, Keshena, Wisconsin, 19 July 1994. The tape of this interview is available to researchers at the Marquette University Archives in Milwaukee, Wisconsin.

${ }^{18}$ Josephine Daniels, oral history interview, 24 May 1994, Blackwell, Wisconsin. The tape of this interview is available to researchers at the Marquette University Archives in Milwaukee, Wisconsin.

${ }^{19} \mathrm{Francis}$ Walker, oral history interview, 23 March 1993, Keshena, Wisconsin. The tape of this interview is available to researchers at the Marquette University Archives in Milwaukee, Wisconsin.

20John Atkins, Annual Report of the Commissioner of Indian Affairs, 21 September 1887, House Executive Document Number 1, 50th Congress, 1st Session, Serial 2542, 20 in Prucha, 1975, 176.

${ }^{21}$ Atkins in Prucha, 1975.

22Tillie Sayresrun, oral history interview, Neopit, Wisconsin, 23 July 1994. The tape of this interview is available to researchers at the Marquette University Archives in Milwaukee, Wisconsin. 
${ }^{23}$ Pywasit.

${ }^{24}$ O'Doric Derenthal, Letter to J.A. Stephens, 11 May 1890, located in the Bureau of Catholic Indian Missions Series 1 correspondence files for Wisconsin, Green Bay Agency, Menominee Reservation, Saint Joseph's Indian Industrial School in the Marquette University Archives, Milwaukee, Wisconsin.

${ }^{25}$ Frank Keshena, oral history interview, Keshena, Wisconsin, 21 July 1994. The tape of this interview is available to researchers at the Marquette University Archives in Milwaukee, Wisconsin.

${ }^{26}$ Daniels.

27Daniels.

28Daniels.

29Daniels.

Sarah Shillinger is an Assistant Professor in the Institute for Ethnic Studies at the University of Wisconsin-LaCrosse. She teaches a variety of courses in ethnic studies, especially in the area of American Indian culture. She specializes in the oral history of American Indians, particularly those of the boarding school era. Currently she is working on an oral history of American Indian education project in the Milwaukee, Wisconsin, area. 